\title{
Epoksida dan Kinetika Minyak Jarak Pagar Sebagai Pemlastis Film Polivinil Klorida
}

\author{
Asep Saefurohman ${ }^{1}$, Purwantiningsih Sugita ${ }^{2}$, Suminar S. Achmadi ${ }^{2}$ \\ 1) IAIN “SMH”Banten, Fakultas Tarbiyah dan Adab,Serang, Indonesia \\ 2) Jurus an Kimia Faku ltas MIPA, IPB Bogor, Indonesia \\ Telp : 081380775639; \\ e-mail: aseps27@yahoo.co.id
}

\begin{abstract}
Abstrak
Tujuan dari penelitian ini adalah menentukan kondisi optimum untuk epoksidasi minyak jarak dengan variasi suhu (T) dan konsentrasi katalis pada waktu reaksi yang sama, mengkarakterisasi hasil epoksidasi atau pemlastis dengan parameter bilangan iodine dan bilangan oksirana serta menentukan orde reaksi dan energi aktivasi menggunakan studi kinetika. Penentuan Ea epoksidasi dilakukan pada kondisi waktu reaksi 12 jam, dengan suhu 50,60, dan $70^{\circ} \mathrm{C}$. Hasil penelitian menunjukkan bahwa kondisi optimum sintesis pemlastis menghasilkan bilangan oksirana $4.2 \%$. Sementara itu, bilangan iodin secara signifikan berkurang dari 2,6-15,3 lebih rendah tetapi bilangan oksirana relatif tinggi, 123,4-205,8 lebih tinggi sebelum dilakukan epoksidasi. Analisis dengan metode respon permukaan menunjukkan bahwa model persamaan matematika untuk bilangan oksirana adalah:17.8733 + 0.5498x $+1.2830 \mathrm{y}-0.0039 \mathrm{z}-0.1960 \mathrm{xy}-0.004 \mathrm{xz}$. Karakterisasi epoksidasi dengan GC-MS menunjukkan waktu retensi 14.809 untuk metil cis $-9,10$ epoksioleat (MW 312). Kinetika reaksi menunjukkan orde ke satu dan konstanta laju untuk bilangan iodine masing-masing adalah: 50,60 , dan $70^{\circ} \mathrm{C}$ adalah $9.97 \times 10^{-2}, 3.4 \times 10^{-2}, 21.34 \times$ $10^{-2}$. Sementara itu, konstanta laju untuk bilangan oksirana adalah $11.28 \times 10^{-2}, 4.39 \times 10^{-2}, 1.89 \times$ $10^{-2}$. Energi aktivasi masing-masing untuk bilangan iodine dan oksirana adalah $24.99 \mathrm{kcal} / \mathrm{mol}$ and $82.296 \mathrm{kcal} / \mathrm{mol}$.
\end{abstract}

Kata Kunci : Epoksidasi, Kinetika, Poli Vinil Klorida, Minyak Jarak, Pemlastis

\begin{abstract}
The purpose of this study was to determine the optimum conditions for the epoxidation of castor oil with temperature variation $(\mathrm{T})$ and the concentration of catalyst in the same reaction time, characterize the epoxidation or plasticizer with iodine numbers and oxirane numbers and determine the reaction order and activation energy using kinetic studies. Determination of Ea made on the reaction time of 12 hours, with temperatures 50,60 ,and $70^{\circ} \mathrm{C}$. The results showed that the optimum conditions of synthesis plasticizer produce numbers oksirana 4.2\%. Meanwhile, the iodine number was significantly reduced from 2.6 to $15.3 \mathrm{oksirana}$ lower, but numbers are relatively high, from 123.4 to 205.8 higher prior to epoxidation. Analysis of the response surface method showed that the mathematical equations to model number oksirana was: $17.8733+0.5498 x+1.2830 y-0.0039 z-0.1960 x y-0.004 x z$. Characterization of epoxidation by GC-MS showed the retention time for methyl cis-9,10-epoxy oleat (MW 312). The kinetics reaction to a single order and rate constants for each of the iodine number was : 50,60 , and $70^{\circ} \mathrm{C}$ were $9.97 \times 10^{-2}, 3.4 \times 10^{-2}, 21: 34 \times 10^{-2}$. Meanwhile, the rate constant for the oksirana number was $11,28 \times 10^{-2}, 4,39 \times 10^{-2}, 1.89 \times 10^{-2}$. The activation energy respectively for iodine numbers andoksirana was $24.99 \mathrm{kcal} / \mathrm{mol}$ and $82.296 \mathrm{kcal} / \mathrm{mol}$.
\end{abstract}

Keywords : Epo xidation, Kinetics, Poly Vinyl Chloride, Oil Distance, plasticizer

\section{PENDAHULUAN}

Plastik merupakan salah satu bahan yang banyak digunakan untuk peralatan rumah tangga, bahan kemasan, peralatan medis, dan sebagainya. Selama pelita V kebutuhan plastik di Indonesia tidak kurang dari 22 ribu ton untuk jenis kantong plastik saja (Sumule \& Suwahyono 2005). Tahun 1999 sampai 2003 
industri berbahan baku plastik di Indonesia tumbuh rata-rata $10 \%$ per tahunnya. Kapasitas produksi termoplastik di Indonesia sampai dengan tahun 2003 mencapai 1.897.823 ton. Proyeksi produksi plastik PVC resin sampai tahun 2008 di Indonesia diperkirakan dapat mencapai 592 ribu ton. Makin banyak penggunaan produk plastik di masyarakat, semakin banyak pula industri dan bahan baku untuk pembuatannya (Hira 2006).

Komponen penyusun plastik terdiri atas dua jenis, yaitu komponen utama berupa polimer (resin) yang merupakan komponen terbesar dari bahan plastik dan aditif. Aditif adalah komponen yang sangat penting pada plastik, walaupun hanya dalam jumlah sedikit tidak lebih dari 5\%. Aditif digunakan pada plastik untuk meningkatkan sifat fungsionalnya seperti ketahanan terhadap api, kekuatan, dan fleksibilitas.

Salah satu zat aditif paling penting adalah pemlastis (plasticizer). Pemlastis dapat menjadikan plastik lebih lentur dan tahan lama. Pemlastis menguasai $65 \%$ dari 7,5 juta ton pasar zat aditif di dunia yang setara dengan US \$7,6 miliar. Kegunaan utama, yaitu sekitar 90\%, digunakan untuk polivinil klorida (PVC). PVC ialah polimer yang digunakan untuk berbagai aplikasi seperti pelapis, pipa, bahan konstruksi, dan botol plastik. Pemlastis menjadikan PVC lebih halus dan lentur, ditambahkan sebanding dengan tingkat kelenturan yang diinginkan. Pasar untuk PVC terus berkembang dan diperkirakan mencapai $8 \%$ per tahun untuk semua aplikasi seperti bahan konstruksi, dan botol plastik (Cavanaugh 1995). Selama lebih dari dua dasawarsa, PVC banyak digunakan karena sifatnya yang tahan akan korosi, isolator yang baik, mudah dibersihkan, dapat didaur ulang, dan dapat digunakan baik dalam bentuk kakunya (rigid) maupun elastis. PVC juga digunakan untuk pengemas makanan seperti plastik lemas atau bening dalam bentuk busa (misalnya kemasan mi instan gelas), sebagai pembungkus buah, dan peralatan medis seperti pengemas untuk darah dan tabung darah, sarung tangan, dan kateter (Prasetyo 2002).

Bahan pemlastis ditambahkan pada PVC agar tidak bersifat kaku dan rapuh dan pemlastis terbesar yang digunakan sekarang ini diambil dari kelompok senyawa ftalat (ester turunan dari asam ftalat). Pemlastis jenis ftalat seperti dietilheksil adipat (DEHA), dietilheksil ftalat (DEHP), dan dioktil ftalat (DOP) merupakan pemlastis berbahan dasar minyak bumi (petrokimia) yang dikategorikan berbahaya dan toksik. Dampak negatif yang ditimbulkan mendukung lahirnya pencarian bahan alternatif sebagai substitusi pemlastis berbasis minyak bumi. Salah satu alternatif sebagai pensubstitusi adalah pemlastis berbasis minyak nabati. Minyak nabati memiliki keunggulan, karena dapat terurai secara alami dan mudah diperbaharui sehingga bersifat ramah lingkungan.

Saat ini minyak nabati yang banyak digunakan dalam industri pemlastis masih didominasi oleh minyak biji bunga matahari, minyak kelapa sawit, dan minyak kedelai (Hazimah et al. 2000). Potensi pasar pemlastis berbahan baku minyak nabati dapat mencapai 50 ribu ton (Priyde dan Rothfus 1999) per tahun. Pemlastis berbasis minyak nabati kedelai, yaitu epoxidized soybean oil (ESO) menguasai pasar pemlastis dunia sekitar $43 \%$, sedangkan pemlastis dari minyak bunga matahari sekitar 9\% (Hill 2000). Minyak jarak pagar mempunyai sifat fisik dan kimia yang mirip dengan minyak kedelai. Kandungan asam lemak takjenuhnya sekitar $46 \%$ yang didominasi asam takjenuh oleat. Senyawa ini berpotensi sebagai bahan dasar untuk membentuk pemlastis kelompok epoksida.

Epoksidasi minyak jarak pagar (MJP) dilakukan dengan penambahan $\mathrm{H}_{2} \mathrm{O}_{2}$ sebagai oksidator dan Amberlit R-120 sebagai katalis. Metode ini pernah digunakan oleh Rios (2003) pada epoksidasi minyak kedelai hanya saja katalis yang digunakan adalah $\mathrm{H}_{2} \mathrm{SO}_{4}$.

Pencirian minyak jarak pagar terepoksidasi (MJPE) dilakukan melalui penentuan bilangan iodin dan bilangan oksirana. Pencirian gugus fungsi MJPE menggunakan FTIR. Selanjutnya, MJPE diaplikasikan pada polimer PVC dengan ragam bobot molekul polimer dan ragam konsentrasi pemlastis.

\section{Tujuan Penelitian}

1. Mengoptimumkan sintesis epoksida minyak jarak pagar melalui ragam suhu (T) dan konsentrasi katalis pada waktu $(t)$ reaksi 12 jam. 
2. Mencirikan pemlastis MJPE melalui bilangan iodin dan bilangan oksirana serta gugus fungsi dengan FTIR.

3. Menentukan persamaan kinetika reaksinya yang meliputi penentuan orde reaksi dan energi aktivasi $\left(E_{a}\right)$.

4. Mengoptimumkan pencampuran antara PVC dengan MJPE dan pencirian sifat reologi filmnya yang meliputi kuat tarik, elastisitas, dan elongasi.

5. Mencirikan film guna melihat teksturnya dan transisi kacanya $\left(T_{\mathrm{g}}\right)$.

\section{METODE PENELITIAN}

\section{Bahan dan Alat}

Minyak jarak pagar, $\mathrm{H}_{2} \mathrm{O}_{2}$, asam asetat glacial, Amberlite R-120. Magnetic stirrer, Penangas listrik, Buret, Spektrofotometer FTIR, Minitab 14, SEM, GCMS.

\section{Optimalisasi Sintesis dan Pencirian Pemlastis Minyak Terepoksidasi}

Pencarian kondisi optimum dilakukan dengan terlebih dahulu mengukur parameter kimia keadaan bahan Minyak jarak pagar. Parameter yang diukur meliputi bilangan iodin, bilangan oksirana, dan bilangan peroksida. Optimalisasi epoksidasi minyak jarak pagar menggunakan dua peubah, yaitu suhu reaksi dan konsentrasi katalis pada waktu reaksi tetap 12 jam (Sumule et al. 2005). Prosedurnya adalah sebagai berikut: larutan pertama sebanyak 10 gram minyak jarak pagar dicampur dengan $0.84 \mathrm{~g}$ asetat glasial dan 2.5 $\mathrm{ml}$ toluena sebagai pelarut. Campuran ini dipanaskan pada suhu $50{ }^{\circ} \mathrm{C}$. Kemudian larutan kedua sebanyak $5.78 \mathrm{~g}\left(\mathrm{H}_{2} \mathrm{O}_{2} 35 \%\right.$ dalam air) dicampurkan dengan $0.25 \mathrm{~g}(\mathrm{~b} / \mathrm{v})$ katalis Amberlite R-120. Larutan kedua ditambahkan tetes demi tetes pada larutan yang pertama sambil diaduk kuat dengan menggunakan pengaduk magnet. Suhu dijaga konstan pada suhu $50{ }^{\circ} \mathrm{C}$ dengan terus diaduk kuat, dan direaksikan selama 12 jam. Sintesis ini dilakukan lagi dengan tahapan sama, tetapi untuk ragam suhu $60{ }^{\circ} \mathrm{C}$, dan $70{ }^{\circ} \mathrm{C}$ dan katalis 0.5, 0.75, dan 1 gram (b/v) Amberlite R-120 sehingga total jumlah perlakuan sebanyak 16.

Pencirian minyak jarak pagar terepoksidasi (MJPE) meliputi penentuan bilangan iodin, dan bilangan oksirana. Analis is gugus fungsi MJPE menggunakan FTIR (Celikay et al. 2002). Perolehan data bilangan iodin dan oksirana dioptimalisasi dengan menggunakan perangkat lunak Minitab 14. Metode tersebut digunakan untuk menggambarkan pengaruh katalis dan suhu $(T)$, terhadap bilangan oksirana atau bilangan iodin.

\section{Penentuan Nilai $E_{a}$ Epoksidasi}

Penentuan $E_{a}$ epoksidasi dilakukan pada kondisi konsentrasi katalis optimum, waktu reaksi 12 jam, pada ragam suhu 50,60, dan 70 ${ }^{\circ} \mathrm{C}$. Tahapan reaksi yang dilakukan sama seperti tahap 1 hanya saja pemakaian reaktan yang digunakan sebanyak 10 kali dari bahan semula. Untuk memantau jalannya reaksi dilakukan pengambilan cuplikan setiap 3 jam. Cuplikan dinetralkan dan dicuci kemudian dianalis is bilangan iodin dan oksirananya. Nilai bilangan iodin dan oksirana setiap suhu diolah untuk mendapatkan parameter kinetika, yaitu orde reaksi dan tetapan laju reaksi $(k)$, yang akan berguna untuk perhitungan energi aktivasi $\left(E_{a}\right)$.

\section{Aplikasi MJPE sebagai Pemlastis pada Polimer PVC}

Sebanyak $50 \mathrm{ml}$ THF dimasukkan ke dalam gelas piala $100 \mathrm{ml}$ yang berisi $9 \mathrm{~g}$ PVC berbobot molekul $62000 \mathrm{~g} / \mathrm{mol}$. Campuran diaduk sampai semua PVC larut seluruhnya. $\mathrm{Ke}$ dalam campuran tersebut dimasukkan sebanyak 1g MJPE sambil terus diaduk sampai homogen pada suhu $25{ }^{\circ} \mathrm{C}$. Selanjutnya campuran dihamparkan pada pelat kaca ukuran $21 \times 21 \mathrm{~cm}^{2}$, diratakan dan didiamkan selama 12 jam untuk menguapkan pelarutnya. Tahapan yang sama dilakukan pada PVC berbobot molekul $43000 \mathrm{~g} / \mathrm{mol}$ dan ragam MJPE 2g, dan 3g sehingga total perlakuan sebanyak 12. Hasil pencampuran ini dianalis is sifat fisiknya meliputi uji kuat tarik, perpanjangan (elongasi), dan elastisitas. Data sifat fisik dianalisis dengan menggunakan perangkat lunak Minitab 14. Selanjutnya dilakukan pencirian produk menggunakan SEM untuk melihat tekstur permukaan hasil pencampuran pemlastis pada PVC.

\section{HASIL DAN PEMBAHASAN}

\section{Optimalisasi Reaksi Epoksidasi MJPE}


Hasil pengukuran awal ketiga parameter tersebut menghasilkan nilai bilangan iodin, $97.4625\left(\mathrm{~g} \mathrm{I}_{2} / 100 \mathrm{~g}\right)$, oksirana dan peroksida berturut-turut $0.0205 \quad(\%)$ dan 0.7294 (eq/1000g). Sintesis epoksidasi MJP menjadi MJPE dilakukan pada waktu tetap 12 jam, dengan ragam suhu 50,60 dan $70{ }^{\circ} \mathrm{C}$ dan ragam konsentrasi katalis $1,2,3$, dan $4 \%$. Data Tabel 1 menunjukkan bahwa sintesis yang dilakukan dengan ragam peubah suhu dan katalis menghasilkan nilai bilangan iodin dan oksirana yang berbeda. Peragaman suhu dan katalis menunjukkan nilai bilangan iodin turun seiring dengan naiknya suhu dan konsentrasi katalis. Nilai bilangan iodin turun seiring naiknya suhu dan konsentrasi katalis, diiringi dengan naiknya nilai bilangan oksirana. Dari hasil pengukuran awal bilangan iodin dibandingkan dengan hasil sintesis epoksidasi diketahui pada suhu $50{ }^{\circ} \mathrm{C}$ untuk bilangan iodin menurun 1.5-4.2 kali dari kondisi awal. Pada suhu $60{ }^{\circ} \mathrm{C}$ bilangan iodin turun antara 1.8-4.23 kali dan pada suhu $70{ }^{\circ} \mathrm{C}$ menurun 2.58-15.3 kali dari kondisi bilangan iodin awal. Demikian pada ragam suhu dan katalis yang berbeda juga menghasilkan nilai bilangan oksirana yang beragam. Nilai bilangan oksirana ini naik seiring naiknya konsentrasi katalis. Sementara itu untuk bilangan oksirana naik 58.5-107.3 kali dari kondisi bilangan oksirana sebelum epoksidasi pada suhu $50{ }^{\circ} \mathrm{C}$. Selanjutnya pada suhu $60{ }^{\circ} \mathrm{C}$ bilangan oksirana naik 87.8-131.7 kali dan pada suhu $70{ }^{\circ} \mathrm{C}$ naik 123.4-205.8 kali dari bilangan oksirana sebelum epoksidasi.

Tabel 1. Hasil sintesis epoksidasi pada ragam peubah suhu dan katalis

\begin{tabular}{lll}
\hline parameter & $\begin{array}{l}\text { suhu } 50{ }^{\circ} \mathrm{C} \mathrm{\&} \\
\text { katalis }(1-4 \%)\end{array}$ & $\begin{array}{l}\text { suhu } 60{ }^{\circ} \mathrm{C} \\
\text { katalis }(1-4 \%)\end{array}$ \\
\hline $\begin{array}{l}\text { Bilangan iodin } \\
\left(\mathrm{g} \mathrm{I}_{2} / 100 \mathrm{~g}\right)\end{array}$ & $63.5-23.7$ & $51.3-23$ \\
$\begin{array}{l}\text { Bilangan oksirana } \\
(\%)\end{array}$ & $1.2-2.2$ & $1.8-.7$ \\
\hline
\end{tabular}

Seluruh data perlakuan hasil sintesis dioptimalisasi dengan metode respons permukaan (response surface method). Pengolahan ini menghasilkan kurva dua dan tiga dimensi yang dapat dianalisis untuk menje laskan pengaruh berbagai respons (suhu dan konsentrasi katalis).

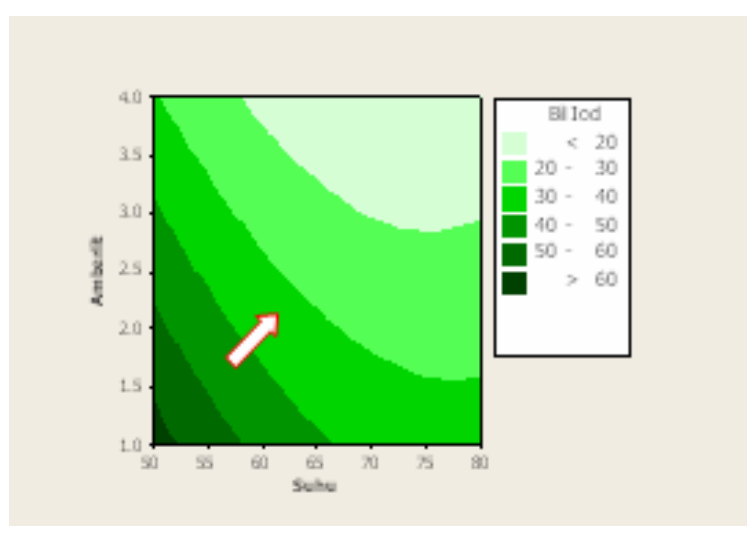

Gambar 1. Kurva hubungan antara suhu dan katalis dan bilangan iodin ( $\diamond$ kecenderungan me mbaik).

Gambar 1 memperlihatkan bahwa naiknya suhu $66-70{ }^{\circ} \mathrm{C}$ dan konsentrasi katalis $3.2-4 \%$ nilai bilangan iodin hasil sintesis turun lebih kecil dari 20 yang ditunjukkan oleh perubahan warna dari warna hijau tua ke warna hijau muda. Pada Gambar 1a juga terlihat bahwa pada suhu reaksi $75-80^{\circ} \mathrm{C}$, dan katalis $4 \%$ ternyata nilai bilangan iodin fluktuatif berada pada kisaran nilai di bawah 20 (warna hijau paling terang). Hal ini mengandung arti bahwa pada suhu yang paling tinggi yaitu antara $75-80{ }^{\circ} \mathrm{C}$ penurunan bilangan iodin bersifat tidak stabil. Hal ini disebabkan oleh bertambahnya penguraian asam perasetat karena di atas suhu $\pm 60-70^{\circ} \mathrm{C}$ penguraian asam perasetat akan lebih cepat dibandingkan epoksidasi ikatan rangkap sehingga akan mengurangi hasil epoksidasi dan ini akan berpengaruh terhadap nilai bilangan iodin (Celikay et al. 2002).

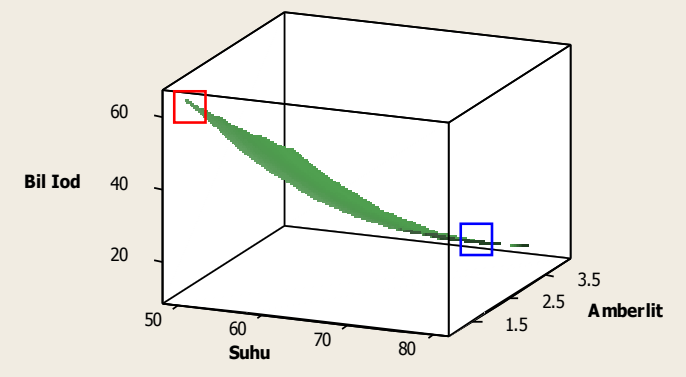

Gambar 2. Kurva hubungan antara respons permu kaan suhu dan katalis terhadap bilangan iodin ( $\square$ = daerah optimum; $\square$ = daerah minimum). 
Kurva respons permukaan (Gambar 2) menjelaskan adanya keteraturan penurunan bilangan iodin dengan adanya kenaikan suhu dan bertambahnya konsentrasi katalis pada daerah optimum dan minimum. Terlihat bahwa nilai bilangan iodin minimum akan diperoleh pada saat suhu $50{ }^{\circ} \mathrm{C}$ dan konsentrasi katalis $1 \%$ (bagian mendatar paling bawah pada kurva). Gambar $4 \mathrm{~b}$ juga memperlihatkan nilai bilangan iodin optimum didapatkan pada saat suhu $70{ }^{\circ} \mathrm{C}$ dan konsentrasi katalis $4 \%$ (kurva yang menjulang ke atas) dengan nilai bilangan iodin 7.12 .

Gambar 3 memperlihatkan pengaruh kenaikan suhu dan konsentrasi katalis terhadap bilangan oksirana. Bilangan oksirana meningkat dengan naiknya suhu dari $50-70{ }^{\circ} \mathrm{C}$ dan konsentrasi katalis dari $1-4 \%$, yang ditunjukkan oleh perubahan warna dari hijau muda ke hijau tua. Bilangan oksirana optimum dicapai pada suhu $70{ }^{\circ} \mathrm{C}$ dan konsentrasi katalis $4 \%$ (daerah bulatan utuh pada kurva).

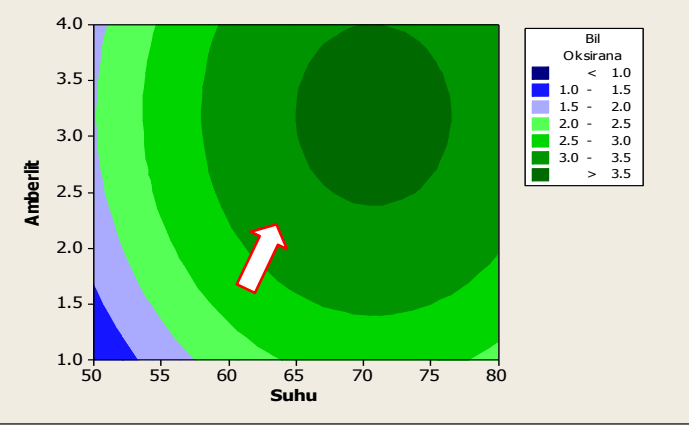

Gambar 3. Kurva hubungan antara suhu dan katalis dan bilangan oksirana $(\nabla$ kecenderungan membaik).

Gambar 4 menjelaskan pengaruh suhu dan katalis terhadap bilangan oksirana hasil epoksidasi pada daerah optimum dan minimum. Kenaikan bilangan oksirana signifikan terjadi pada daerah rentang suhu 50$70{ }^{\circ} \mathrm{C}$ pada kondisi katalis $1-4 \%$ (kurva menjulang dari bawah ke atas). Pada suhu yang lebih tinggi yaitu $\pm 80{ }^{\circ} \mathrm{C}$ bilangan oksirana turun dan ditunjukkan dengan penurunan pada daerah lengkungan kurva bagian ujung paling atas yang merupakan titik balik kenaikan bilangan oksirana atau penurunan bilangan oks irana. Menurut Goud et al. (2006), konversi ikatan rangkap menjadi oksirana dengan cepat akan terjadi pada suhu $80-85{ }^{\circ} \mathrm{C}$ dalam kisaran waktu yang singkat, yaitu 3-6 jam reaksi. Pada proses sintesis epoksidasi, untuk mencegah reaksi eksotermik tidak terkendali, maka setiap tingkat kisaran suhu dipisahkan dengan perbedaan $10{ }^{\circ} \mathrm{C}$.

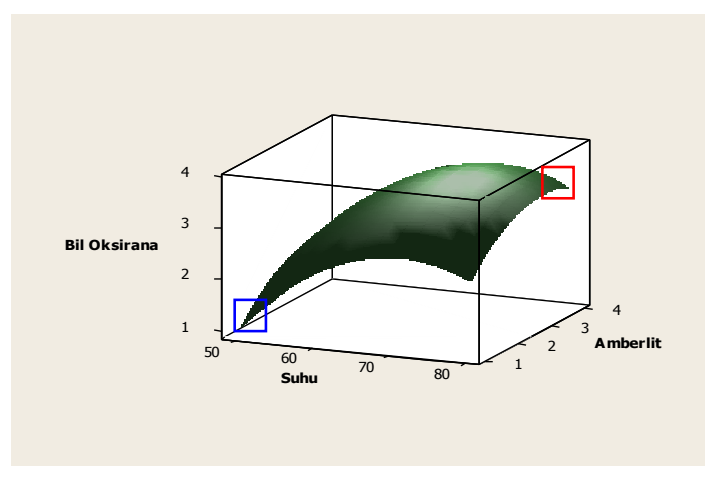

Gambar 4. Kurva hubungan antara respons permukaan suhu dan katalis terhadap bilangan oksirana ( $\square$ = daerah optimum; $\square$ = daerah minimu $\mathrm{m}$ ).

Peningkatan suhu akan mendorong pembentukan asam perasetat. Hal ini akan mempercepat laju epoksidasi, tetapi sekaligus meningkatkan laju hidrolisis, sehingga terjadi pembukaan cincin oksirana (Campanela dan Baltanas 2005).

Reaksi epoksidasi optimum terjadi pada kondisi suhu $70{ }^{\circ} \mathrm{C}$ dan katalis Amberlite IR-120 4\% dalam waktu reaksi 12 jam. Pada kondisi reaksi ini menghasilkan nilai bilangan oksirana sebesar $4.2 \%$.

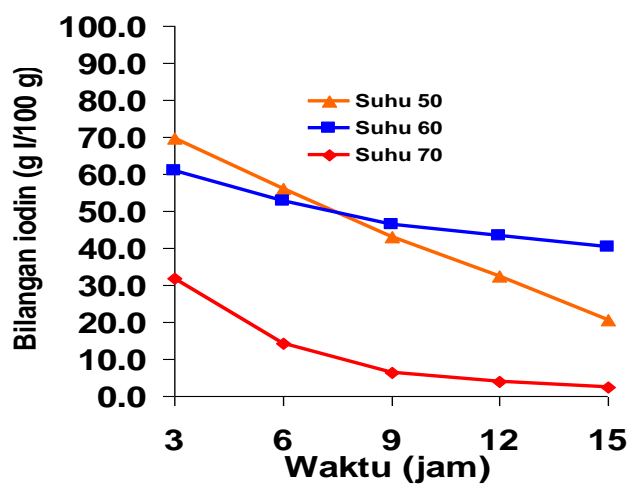

(a)

Gambar 5 (a). Kurva hubungan antara bilangan iodin terhadap waktu. 


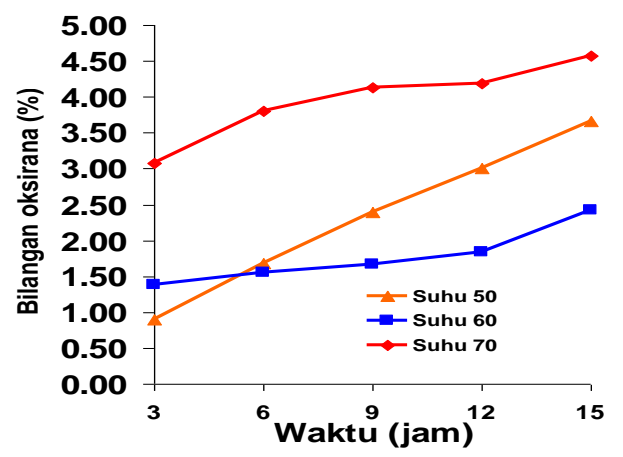

(b)

Gambar 5(b). Kurva hubungan antara bilangan oksirana terhadap waktu

Gambar 5(a) memperlihatkan nilai bilangan iodin MJPE turun 13-14 kali dari kondisi bilangan iodin awal, sebaliknya bilangan oksirana MJPE meningkat 208 kali dari kondisi awal. Hal ini membuktikan te lah terjadinya reaksi oksidasi. Bilangan oksirana 5(b) $4.2 \%$ lebih rendah bila dibandingkan dengan nilai bilangan oksirana pada epoksidasi minyak kedelai $\pm 6.9 \%$ (Petrović et al. 2001), nilai tersebut di atas lebih tinggi daripada hasil epoksidasi menggunakan metil ester jarak pagar dengan waktu, suhu dan katalis yang sama (Sumule et al. 2005), yaitu 3.38\% dan juga lebih tinggi dengan katalis zeolit (Diana 2007), yaitu $1.33 \%$ serta bentonit (Wahid 2007), yaitu $1.36 \%$.

Berdasarkan pengolahan dengan software Minitab 14 untuk melihat interaksi setiap respons (suhu dan katalis) maka didapatkan hasil analisis koefisien kuadratik yang menunjukkan bahwa model persamaan matematika untuk optimasi ini adalah: bilangan oksirana $=17.8733+0.5498 \mathrm{x}+$ $1.2830 y-0.0039 z-0.1960 x y-0.004 x z$ dengan nilai $\mathrm{R}-\mathrm{Sq}$ dan $\mathrm{R}-\mathrm{Sq}$ (adj) berturutturut adalah $75.9 \%$ dan $63.8 \%$. Sementara itu analisis keragaman atau ANOVA menunjukkan bahwa nilai P (0.001) lebih kecil dari taraf $\alpha(5 \%)$. Oleh karena itu dapat disimpulkan bahwa semua peubah suhu dan katalis memiliki pengaruh nyata pada bilangan oksirana.

\section{Identifikasi dan Pencirian MJPE Optimum dengan FTIR dan GC-MS}

Daerah serapan $\mathrm{C}=\mathrm{C}$ pada MJP terdapat pada $1652.82 \mathrm{~cm}^{-1}$ dan pada MJPE spektrum ini berkurang atau tidak terlihat dengan bertambahnya tingkat epoksidasi karena mengalami pemutusan dan mengikat oksigen untuk membentuk cincin oksirana. Pada MJPE juga terdapat serapan pada $729.24 \mathrm{~cm}^{-1}$ yang merupakan serapan khas untuk gugus fungsi epoksi (Celikay et al. 2002).

Analisis GC-MS untuk mengidentifikasi senyawa epoksida yang terbentuk didapatkan bahwa pada MJPE dengan waktu retensi 14.809 dan luas area $4.66 \%$ terdapat senyawa metil cis-9,10-epoksioleat dengan senyawa $\mathrm{C}_{19} \mathrm{H}_{36} \mathrm{O}_{3}$ dan bobot molekulnya $(\mathrm{BM}=312)$. Selain terdapat senyawa lain seperti asam laurat, metil palmitat, asam palmitat, metil stearat, asam oleat. Data ini menjelaskan bahwa telah terjadi reaksi epoksidasi dari MJP menjadi MJPE.

\section{Optimalisasi Pencampuran PVC dengan Pemlastis}

Pencampuran PVC dengan pemlastis MJPE dilakukan pada keadaan fase cair-cair menggunakan pelarut THF. Hasil pencampuran tersebut di uji dengan menggunakan alat uji tarik setelah dibentuk dumbell dengan menggunakan alat Instron ASTM-D-1822. Nilai rata-rata dari hasil uji tarik dapat dilihat pada Tabel 6. Pencampuran dan penambahan pemlastis pada PVC dapat mengubah sifat fisik polimer tersebut, terlihat dari adanya perubahan nilai kuat tarik, elastisitas, dan elongasinya. Terlihat bahwa nilai kuat tarik pada film PVC dengan bobot molekul $63.000 \mathrm{~g} / \mathrm{mol}$ semakin menurun dengan bertambahnya konsentrasi pemlastis (B-D). Sementara itu pada film PVC dengan bobot molekul $43.000 \mathrm{~g} / \mathrm{mol}$ juga kuat tarik turun nilai seiring kenaikan konsentrasi pemlastis $(\mathrm{F}-\mathrm{H})$. Hal ini menunjukkan bahwa kenaikan konsentrasi pemlastis akan menurunkan nilai kuat tarik pada film PVC. Menurut Krauskof dan Godwin (2003) menurunnya nilai kuat tarik pada PVC disebabkan oleh terdifusinya pemlastis ke dalam polimer sehingga melemahkan interaksi antarpolimer dan mencegah terbentuknya jaringan yang kaku pada polimer. Sementara itu nilai elastisitas dan elongasi naik seiring kenaikan konsentrasi pemlastis pada film PVC. 
Tabel 6 Data hasil uji kuat tarik

\begin{tabular}{crrl}
\hline Contoh & $\begin{array}{r}\text { Kuat tarik } \\
\left(\mathrm{kg} / \mathrm{cm}^{2}\right)\end{array}$ & $\begin{array}{r}\text { Elastisitas } \\
(\%)\end{array}$ & Elongasi \\
\hline $\mathrm{A}$ & 523.20 & 20 & 1.2 \\
$\mathrm{~B}$ & 350.00 & 204 & 3.0 \\
$\mathrm{C}$ & 217.24 & 250 & 3.5 \\
$\mathrm{D}$ & 75.09 & 284 & 3.8 \\
$\mathrm{E}$ & 368.44 & 50 & 1.5 \\
$\mathrm{~F}$ & 220.14 & 150 & 2.5 \\
$\mathrm{G}$ & 181.05 & 150 & 2.5 \\
$\mathrm{H}$ & 54.80 & 200 & 2.0 \\
\hline
\end{tabular}

$$
\begin{aligned}
& \text { Keterangan: } \\
& \mathrm{A} \quad=\text { Tipe } 1 \mathrm{~b} \text { lanko (BM:63.000) } \\
& \mathrm{B} \quad=\text { Tipe } 1+1 \mathrm{~g} \text { MJPE } \\
& \mathrm{C} \quad=\text { Tipe } 1+2 \mathrm{~g} \text { MJPE } \\
& \mathrm{D} \quad=\text { Tipe } 1+3 \mathrm{~g} \text { MJPE } \\
& \mathrm{E} \quad=\text { Tipe } 2 \text { blanko }(\mathrm{BM}: 43.000) \\
& \mathrm{F} \quad=\text { Tipe } 2+1 \mathrm{~g} \mathrm{MJPE} \\
& \mathrm{G} \quad=\text { Tipe } 2+2 \mathrm{~g} \text { MJPE } \\
& \mathrm{H} \quad=\text { Tipe } 2+3 \mathrm{~g} \mathrm{MJPE}
\end{aligned}
$$

Selanjutnya, data uji tarik yang diperoleh diolah menggunakan perangkat lunak Minitab 14 untuk melihat interaksi atau respons data terhadap beberapa faktor, di antaranya ragam jumlah pemlastis dan bobot molekul PVC. Menurut Biju et al. (2007) pemlastis yang berasal dari senyawa terepoksidasi tinggi akan berinteraksi kuat dengan PVC dan menambah kompatibilitas polimer sehingga akan berpengaruh terhadap kuat tarik, elastis itas dan elongasi polimer. Gambar 6 menunjukkan kurva dua dimensi yang memperlihatkan pengaruh konsentrasi pemlastis dan bobot molekul PVC terhadap kuat tarik. Terlihat bahwa dengan naiknya konsentrasi pemlastis pada ragam peubah bobot molekul maka nilai kuat tarik turun yang ditunjukkan oleh perubahan warna dari biru tua menjadi hijau.

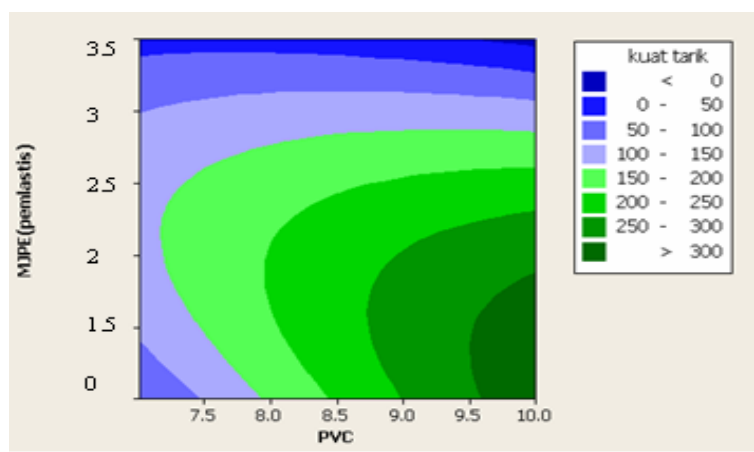

Gambar 6. Kurva hubungan antara PVC dan MJPE (pemlastis) dan kuat tarik.

Gambar 7 menjelaskan pengaruh PVC dan pemlastis terhadap elastisitas. Berdasarkan hasil pada Tabel 6 terlihat bahwa kenaikan konsentrasi pemlastis akan menaikan nilai elastisitas film PVC. Pada PVC dengan bobot molekul $62.000 \mathrm{~g} / \mathrm{mol}$ tanpa penambahan pemlastis (blanko) nilai elastisitas sangat kecil dan naik tajam seiring kenaikan penambahan konsentrasi pemlastis (A-D). Kenaikan nilai elastisitas ini juga terjadi pada PVC dengan bobot molekul $43.000 \mathrm{~g} / \mathrm{mol}(\mathrm{E}-\mathrm{H})$.

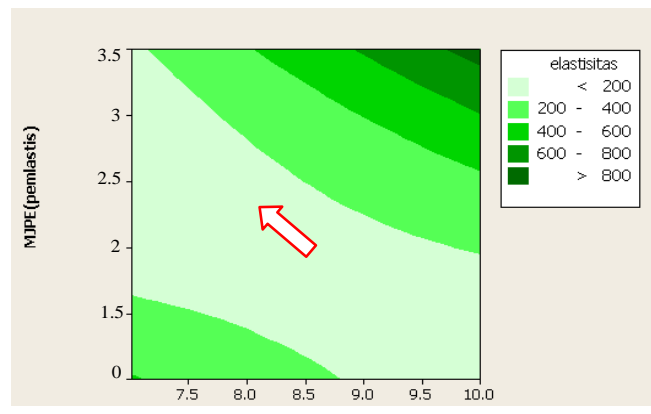

Gambar 7 Kurva hubungan antara PVC dan MJPE (pe mlastis) dan elastisitas.

Menurut Biju et al. (2007), penambahan pemlastis pada polimer mempengaruhi kelenturan polimer dengan menurunkan sifat getas dan kaku pada polimer sehingga menaikan elastisitas pada polimer. Gambar 6 menjelaskan pengaruh ragam pemlastis dan bobot molekul terhadap elastisitas. Pada konsentrasi pemlastis antara 1.6-3 gram, nilai elastisitas konstan pada kisaran 200 yang ditunjukkan oleh warna biru muda terang pada kurva. 


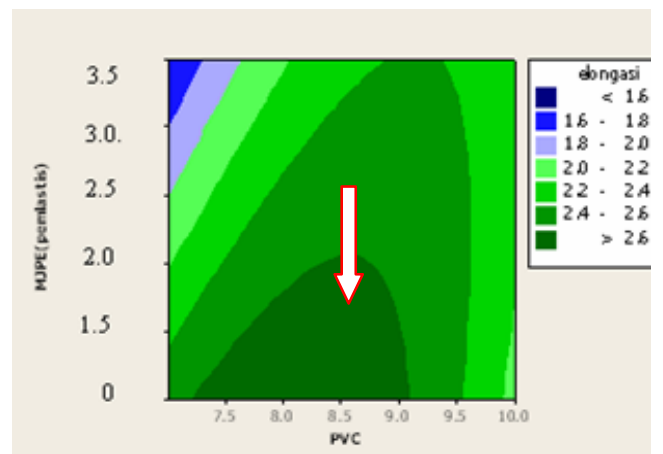

Gambar 8. Kurva hubungan antara PVC dan MJPE (pemlastis) dan elongasi.

Gambar 8 menjelaskan pengaruh pemlastis dan bobot molekul PVC terhadap nilai elongasi film PVC. Nilai elongasi bertambah seiring kenaikan konsentrasi pemlastis. Elongasi terbesar didapatkan pada saat kisaran pemlastis $3 \mathrm{~g}$ yang menghasilkan nilai elongasi lebih besar 2.6. Hal ini disebabkan oleh adanya plastisasi polimer yang disebabkan oleh penambahan pemlastis sehingga menaikan elongasi pada polimer. Elongasi bertambah besar seiring kenaikan jumlah pemlastis yang ditambahkan ( Biju et al. 2007). Pada PVC dengan berat molekul $43.000 \mathrm{~g} / \mathrm{mol}$, nilai elongasi dan kuat tarik pada perbandingan PVC:MJPE (7:3) yaitu 2 lebih rendah dari nilai elongasi pada perbandingan PVC:MJPE (8:2) yaitu 2.5. Hal ini mungkin disebabkan oleh distribusi pemlastis yang tidak merata pada proses pencampuran PVC dengan pemlastis sehingga tidak terdifusi dengan baik pada film PVC.
Selanjutnya data keseluruhan kuat tarik, elastisitas dan elongasi diolah dengan Minitab 14 untuk mencari nilai optimum kondisi pencampuran PVC dengan pemlastis dan nilai optimum adalah pada kondisi pencampuran PVC dan pemlastis 7:3.

\section{Pencirian Film dengan SEM}

Optimalisasi pencampuran PVC dengan pemlastis menghasilkan nilai optimum pada kondisi PVC $7 \mathrm{~g}$, pemlastis $3 \mathrm{~g}$. Selanjutnya dilakukan pencirian film PVC dengan SEM. Hasil SEM permukaan film tanpa pemlastis (Gambar 9a) memperlihatkan tekstur kasar yang berlubang. Hal ini menunjukkan tekstur film PVC tanpa pemlastis memiliki permukaan yang tidak merata pada kisi-kisinya dan tidak homogen menyebabkan terperangkapnya gelembung-gelembung udara sehingga permukaan film terlihat kisut dan berlubang. Gambar 9b memperlihatkan keadaan yang sebaliknya, pada permukaan hasil foto SEM yang menggunakan pemlastis permukaan filmnya memperlihatkan keseragaman dan tekstur yang merata dan homogen serta memiliki tekstur yang halus. Hal ini disebabkan oleh film yang menggunakan pemlastis memiliki tekstur yang seragam dan homogen karena pemlastis mengisi kisi-kisi antarruang polimer sehingga permukaan atau tekstur film menjadi halus, tidak kisut, dan tidak berlubang serta merata dibandingkan dengan tekstur permukaan film tanpa pemlastis.
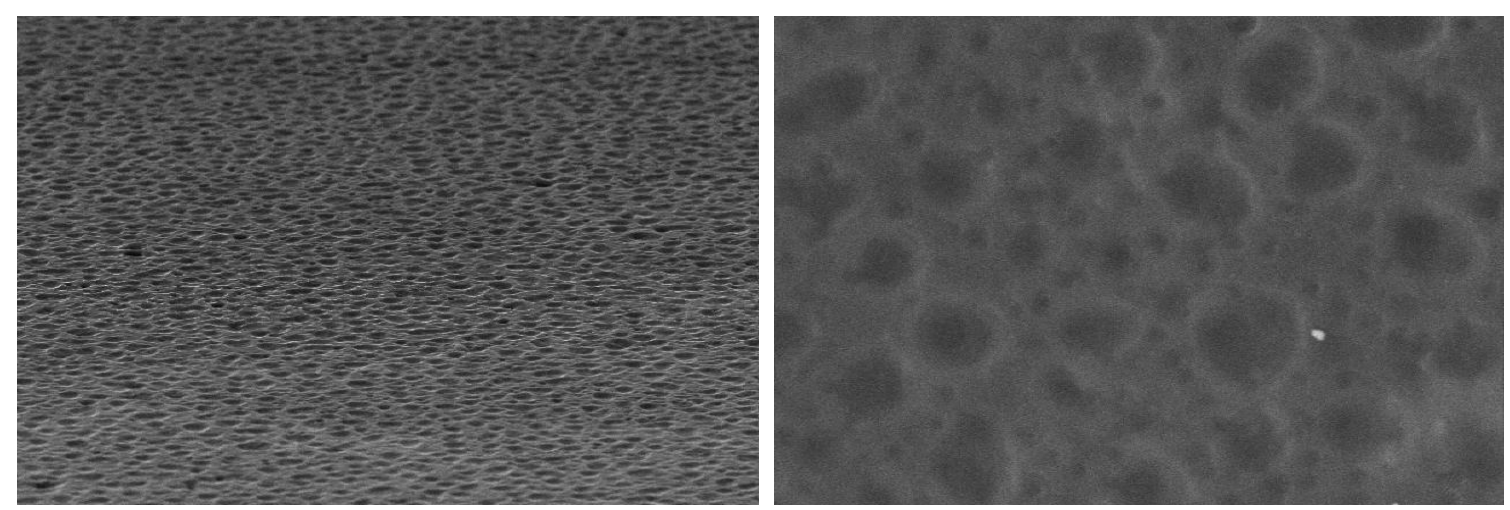

Gambar 9 (a) Foto SEM tekstur permukaan film tanpa pemlastis pada perbesaran 7500x ; (b) Foto SEM tekstur permukaan film dengan pemlastis pada perbesaran $7500 x$. 


\section{Pengukuran $T_{g}$ Film dengan DSC}

Tabel 7 menjelaskan hasil pengukuran hasil pencampuran PVC dengan pemlastis atau film yang menghasilkan nilai transisi kaca yang berbeda pada ragam pencampuran PVC dan pemlastis yang optimum.

Tabel 7. Data hasil uji $\mathrm{T}_{\mathrm{g}}$ film dengan DSC

\begin{tabular}{lll}
\hline No & Identitas sampel & $\mathbf{T}_{\mathbf{g}}\left({ }^{\mathbf{0}} \mathbf{C}\right)$ \\
\hline 1 & Blanko PVC BM 62000 & 43.6 \\
2 & Blanko PVC BM 43000 & 41.8 \\
3 & PVC BM 62000 +Pemlastis (7:3) & 42.7 \\
4 & PVC BM 43000 +Pemlastis (7:3) & 40.9 \\
\hline
\end{tabular}

Dari Tabel 7 menjelaskan bahwa nilai transisi kaca film untuk blanko PVC dengan bobot molekul $62000 \mathrm{~g} / \mathrm{mol}$ setelah ditambahkan pemlastis mengalami penurunan nilai transisi kaca dari 43.6 menjadi $42.7{ }^{\circ} \mathrm{C}$ (Termogram DSC selengkapnya dapat dilihat pada Lampiran 26-28). Sementara itu untuk PVC dengan bobot molekul $43000 \mathrm{~g} / \mathrm{mol}$ nilai transisi kaca turun dari 41.8 menjadi $40.9^{\circ} \mathrm{C}$. Nilai transisi kaca secara teoritis untuk PVC adalah berkisar $81-87{ }^{\circ} \mathrm{C}$, sedangkan hasil pengukuran film PVC blanko pada penelitian ini nilai berkisar $40-43{ }^{\circ} \mathrm{C}$. Hal ini disebabkab oleh PVC komersial yang digunakan belum murni atau terkontaminasi pada proses pembuatannya sehingga nilai $\mathrm{T}_{\mathrm{g}}$ yang teridentifikasi berbeda.

Sementara itu susunan rantai karbon panjang yang terdapat pada pemlastis akan menyebabkan interaksi antara polimer dengan pemlastis tidak sempurna. Interaksi yang sempurna antara polimer dengan pemlastis akan tercapai jika terjadi introduksi yang cukup dari gugus epoksi pada rantai belakang senyawa diena yang menunjukkan tingkat epoksidasi yang tinggi pada pemlastis. Menurut Biju et al. (2007), interaksi yang kuat antara bahan PVC dengan pemlastis akan menurunkan nilai trans isi kaca $\left(T_{g}\right)$ film hasil pencampuran PVC dengan pemlastis berdasarkan interaksi molekular polar-polar. Hal ini disebabkan oleh kecenderungan semakin pendek ikatan pada rantai polimer akan semakin menurunkan nilai transisi kaca film hasil pencampuran PVC dengan pemlastis dan menunjukkan terjadinya plastisasi.
Plastisasi pada PVC oleh pemlastis akan memodifikasi sifat bahan film dan memengaruhi suhu $\mathrm{T}_{\mathrm{g}}$ polimer. Sementara itu, turunnya transisi kaca pada film hasil pencampuran PVC dan pemlastis pada penelitian ini tidak terlalu banyak disebabkan oleh konfigurasi rantai karbon pemlastis yang berasal dari MJP relatif panjang sehingga interaksi molekular antara PVC dan pemlastis tidak besar sehingga perbedaan nilai $\mathrm{T}_{\mathrm{g}}$ antara blanko PVC dan hasil pencampuran PVC dan pemlastis tidak signifikan. Sementara itu perbedaan nilai $\mathrm{T}_{\mathrm{g}}$ antara blanko $\mathrm{PVC}$ dengan hasil pencampuran PVC dan pemlastis akan signifikan jika pemlastis yang digunakan adalah berasal dari petrokimia seperti dioktil ftalat (DOP) karena konfigurasi karbok siklik yang dimiliki senyawa DOP menyebabkan interaksi yang lebih baik antara pemlastis dengan polimer.

\section{KESIMPULAN DAN SARAN}

Kesimpulan dari penelitian ini adalah bahwa kondisi optimum sintesis epoksidasi terjadi pada suhu $70{ }^{\circ} \mathrm{C}$ dan katalis Amberlite IR-120 4\% dalam waktu reaksi 12 jam, dengan bilangan oks irana $4.2 \%$. Daerah serapan $\mathrm{C}=\mathrm{C}$ pada MJP pada $1652.82 \mathrm{~cm}^{-1}$ dan pada MJPE tidak menunjukkan bertambahnya tingkat epoksidasi mungkin karena pemutusan dan mengikat oksigen untuk membentuk cincin oksirana. Pada MJPE juga terdapat serapan pada $729.24 \mathrm{~cm}^{-1}$ yang merupakan serapan khas gugus fungsi epoksi. Analisis GC-MS mengidentifikasi senyawa epoksida sejumlah $4.66 \%$ berupa senyawa metil cis-9,10epoksioleat dengan senyawa $\mathrm{C}_{19} \mathrm{H}_{36} \mathrm{O}_{3}$ yang bobot molekulnya 312 .

Hasil analis is menunjukkan bahwa epoksidasi MJP menjadi MJPE menghasilkan orde satu dengan nilai koefisien determinasi, $R^{2}$, pada suhu 50,60 , dan $70{ }^{\circ} \mathrm{C}$ berturut-turut $0.97860,0.97010,0.9811$, sedangkan untuk bilangan oksirana nilai koefisien determinasi pada suhu 50,60 , dan $70{ }^{\circ} \mathrm{C}$ berturut-turut $0.9375,0.9225,0.9369$ dan $E_{a} 24.99 \mathrm{JK} / \mathrm{mol}$ dan $E_{a} 82.296 \mathrm{JK} / \mathrm{mol}$. Pencampuran optimum PVC dan MJPE 7 g PVC dan 3 gram MJPE menghasilkan penurunan nilai kuat tarik, dan kenaikan elastisitas serta elongasi. Nilai transisi kaca $\left(T_{\mathrm{g}}\right)$ film mengalami penurunan dengan adanya penambahan pemlastis. Pada Film dengan perbandingan PVC:pemlastis 7:3 
untuk bobot molekul PVC $62000 \mathrm{~g} / \mathrm{mol}$ mengalami penurunan $\mathrm{Tg}$ dari 43.6 menjadi $42.7{ }^{\circ} \mathrm{C}$. Sementara itu untuk hasil pencampuran PVC:pemlastis 7:3 untuk bobot molekul PVC $43000 \mathrm{~g} / \mathrm{mol} \mathrm{T}_{\mathrm{g}}$ turun dari 41.8 menjadi $40.9^{\circ} \mathrm{C}$.

\section{Saran}

Perlu dilakukan penelitian lanjutan untuk melihat nilai transisi kaca $(T g)$ untuk pencirian hasil pencampuran $\mathrm{PVC}$ dengan pemlastis sehingga bentuk dan morfologi polimer dapat teridentifikasi dengan baik.

\section{DAFTAR PUSTAKA}

1. Biju $\mathrm{K}$ et al. 2007. Plasticizing Effect of Epoxidized natural rubber on PVC/ELNR blends preapared by solution blending. Material Science-Poland 25:919-932.

2. Campella B, Baltanas M. 2005. Degradation of the Oxirane Ring of Epoxidized Vegetable Oils in Liquid-Liquid Systems: Reactivity with Solvated Acetic and Peracetic Acids. Latin American Applied Research, 35:211-216.

3. Cavanaugh T. 1995. Plastics additives'95. Chemical Marketing Reporter p. SR. 10.(terhubungberkala).Http://www.carbohydrat eeconomy.org/library/

uploadedfiles/Biochemical Plasticizers.html. [26 Desember 2006].

4. Celikay R et al. 2002. Epoxidation of Partially Norbornylized Linseed Oil. Macromol, Chem 203:2042-2057.

5. Goud V et al. 2006. Epoxidation of Karanja (Pongamia glabra) Oil by $\mathrm{H}_{2} \mathrm{O}_{2}$. JAOCS, $\mathrm{Vol}$ 83:635-640.

6. Hazimah AH, Salimah A, Ahmad I. 2000. Epoxidation palm oil creates exciting avenues for palm-based industrilisation. Forum information service ISSN 0218-5726.

7. Hill K. 2000. Fats and oils as oleochemical raw materials. Pure Appl Chem 72: 12551254.

8. Hira N. 2006. Industri Plastik Indonesia. Jakarta. Ban k Ekspor Indonesia.

9. Petrovic ZS et al. 2001. Kinetics of in situ Epoxidation of Soybean Oil in Bulk Catalyzed by Ion Exchange Resin. JAOCS 78:3-15.

10. Prasetyo W. 2002. PVC Modern Plastics,. Di dala m: Peranan Penelitian dan Pengembangan Ilmu Pengetahuan dan Teknologi Bahan dalam
Mewujudkan Kemandirian Teknologi dan Meningkatkan Sumber Daya Alam lokal. Prosiding Pertemuan Ilmiah Ilmu Pengetahuan dan Teknologi Bahan; Jakarta Mei 2002. hlm.31-38.

11. Priyde E, Rothfus J. 1999. Industrial and Nonfood Uses of Vegetable Oils. New York: McGraw-Hill.

12. Rios LA. 2003. Heterogeneously catalyzed reactions with vegetable oils: Epoxidation and nucleophilic epoxide ring opening with alcohol [Disertasi]. The Institute of Chemical Technology and Heterogenous Catalysis. University RWTH-Aachen.

13. Sumule O, Suwahyono U. 2005. Bioplastik: Produk Teknologi Tinggi Berwawasan Lingkungan. Jakarta: Badan Pengkajian dan Penerapan Teknologi. 